UDC 624.042

\title{
SOME ASPECTS OF VERTICAL CYLINDRICAL SHELLS' CALCULATION AT THE UNSYMMETRICAL LOAD
}

\author{
A.V. Makhinko ${ }^{1}$, \\ Doctor of Technical Sciences, Senior Research Officer, \\ the Head of sScientific and Technological Department \\ N.O. Makhinko ${ }^{2}$, \\ Candidate of Engineering Sciences, Associate Professor at the Department of Computer \\ Technologies of the Construction \\ ${ }^{1}$ Ethual" LLC \\ Bortnytska street 1, Petropavlovskaya village, Borispol district, Kyiv region, 08341, Ukraine; e-mail. \\ pasargada1981@gmail.com \\ ${ }^{2}$ National Aviation University \\ Kosmonavt Komarov avenue, 1,03058,Kyiv,Ukraine; e-mail:pasargada1981@gmail.com
}

The paper deals with the influence of the harmonica's parameters of the unsymmetrical load, which is represented by trigonometric cosine-series. The analysis is based on the results of practical calculations of the silo capacities' constructions by using the moment theory on the influence of the changeable wind load. The model of the silos construction is schematized in the form of orthotropic cylindrical shell of revolution with different thickness of the wall in meridional and circular directions, which allow approximately, considering the existence of vertical stiffeners.

Keywords: cylindrical shell, unsymmetrical load, silo capacity, stiffeners, wind effect, harmonica of the load.

Introduction. The deflected mode of the cylindrical shell, which is strengthened by vertical stiffeners in conditions of the unsymmetrical radial load, is characterized by pretty difficult processes of internal efforts' changing and processes of deformation in its separated elements. The detailed analysis of all calculation's aspects of such construction allows using received results for real construction projects in the future.

Problem statement and its solving. A cylindrical shell is the classic model of vertical steel capacities for grain storage. The main changeable load for the given type of construction is the wind pressure, which is well approximated by the series of cosines. The non-uniform distribution of the wind load is considered by the function of aerodynamic coefficient which in its turn is factorized into the finite trigonometric series [1]. Practical calculations of silos is limited by using only first 5-6 terms of series, but the sufficient argumentation of this fact is not given.

The analysis of recent research and publications. The classic problem of calculation of cylindrical shells of revolution by using moment or momentless theories is well described in works of famous native researchers $[2,3,4,5]$. With respect to the real constructions of silo capacities it should be mentioned works of foreign scientists $[6,7,8,9]$. Defining the internal efforts in elements of steel cylindrical capacities under the axially symmetric load is analyzed in the authorial research [10]. 
Formulation of the paper's purpose. The procedure of factorization of external unsymmetrical load is simplifying determination of the functional connection between parameters of the load and the deflected mode [1], since consequently calculation could be used to every constituent of the load separately. Probably in this case the parameter of the load's harmonica is the main factor, which influence deflected mode of the construction. Besides, the given value is influence the body of the shell differently, depending on the relation of its overall sizes, thickness and invoice of the wall (in real capacities of storage the body could be made of flat or corrugated plates of different thickness).

If terms of series of aerodynamic coefficient's factorization of wind load are growing, then, correspondingly, the accuracy of calculation for vertical cylindrical silos is growing, but the complexity of calculations is also growing. Consequently, there is a natural question about sufficient and minimum possible number of terms of series, and, correspondingly, the reaction of the construction.

The main research material. For the solution of the formulated purpose it were conducted calculations of the silo capacities, which differed in height ( $H_{w}=10 \ldots 30 \mathrm{~m}$ ) and in thickness of the main elements, such as wall and ribs, $\left(t_{w}=t_{p}=2 \ldots 6 \mathrm{~mm}\right)$ at the unsymmetrical wind load by using the moment theory. The model of the silo's construction was schematized in the form of the orthotropic cylindrical shell of revolution, which is hardly clamped near the basis.

The constituent of the wind load was presented in the form of

$$
W_{k}=A_{k} \cos (k \varphi),
$$

where $A_{k}$ is the amplitude value of the $k$ constituent; $\varphi$ is the corner of the attack, which consider wind direction. The non-uniform distribution of the wind load around the perimeter of the capacity was considered through the function of aerodynamic coefficient $C_{a e r}(\varphi)$

$$
C_{a e r}(\varphi)=a_{0}+a_{1} \cos (\varphi)+a_{2} \cos (2 \varphi)+\ldots+a_{k} \cos (k \varphi)+\ldots+a_{m} \cos (m \varphi),
$$

where $a_{k}$ are coefficients of factorization of the aerodynamic coefficient $C_{a e r}(\varphi)$ into the trigonometric series [1].

The unknown internal efforts and displacements expressed through the function $\xi_{k}(x)$, which was found by solving the linear differential equation [1]

$$
\frac{d^{4} \xi_{k}(x)}{d x^{4}}+4 \eta_{w, k}^{4} \xi_{k}(x)=4 \eta_{w, k}^{4} \xi_{k, 0},
$$

where $\eta_{w, k}^{4}$ is the value, which considers rigid characteristics of the shell in predetermined conditions of $k$ harmonica of the load; $\xi_{k, 0}$ is the coefficient of proportion, which has dimension of the function $\xi_{k}(y)$ and considers the character of the harmonious load $W_{k}$.

Total deflected mode of the capacity is defined by the way of adding separate deflected modes of the $k$ influence

$$
R_{D}(y, \varphi)=\sum_{k=0}^{m} a_{k} R_{k}(y, \varphi),
$$


where $R$ is the generalized parameter of reaction $R=\sigma_{p} \vee \tau \vee w \vee v \vee u ; \sigma_{p}$ and $\tau$ are normal and contacting loads, correspondingly; $u, w, v$ are the main displacements (longitudinal, radial and circular); $y=x / H_{w}$ is the nondimensional height, which is equal to the relation of the coordinate $x$ and the height of the capacity $H_{w}$.

In the common procedure of defining internal efforts and displacements we will denote the next moments. Zero term of series (4) corresponds to the axially symmetric load, and, consequently, it does not cause any efforts in ribs. The second constituent $a_{1} R_{1}$ causes an ordinary bend of the capacity. The other terms of series (4) when $k \geq 2$ is expressed by the formula

$$
R_{D}(y, \varphi)=\sum_{k=1}^{m} r_{D, k}(y) \cos (k \varphi), \quad \vee \quad R_{D}(y, \varphi)=\sum_{k=1}^{m} r_{D, k}(y) \sin (k \varphi),
$$

where $r_{D, k}(y)$ is the value, which is corresponding the reaction of the capacity in the point $(y ; \varphi=0)$ on the function's cosine (sinus) of reaction's changing by $\varphi$.

The received values of reaction were reflected in the non-dimensional polar system of coordinates (see fig. 1) in the form of dependence

$$
\rho_{D}(\varphi)=R_{D} / \max \left(R_{D}\right) \text {. }
$$

Results of the capacities' calculation in the form of the scheme of the body displacements of capacities are partially given in fig. 2 .
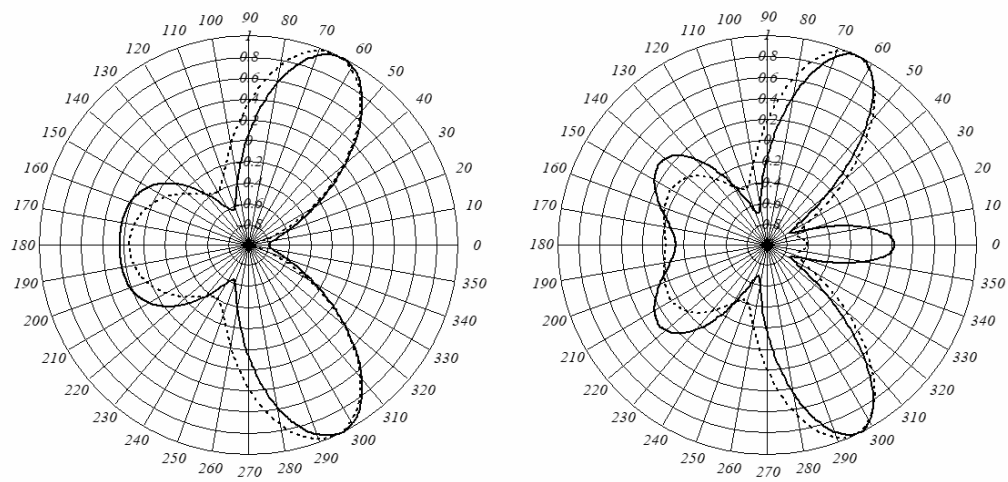

Fig. 1. Introduction of the capacities' reactions in the non-dimensional polar coordinates

The analysis of calculations showed that differences are shown not only quantitatively, but also qualitatively, depending on values of elongation $\Delta_{w}$ (relation of the height and the diameter of the capacity), the thickness of the body $t_{w}$, the thickness of the vertical ribs $t_{p}$ and their number $n_{p}$.

For low capacities with relatively small index of rigidity ribs and covering of zero direction, adjoining to them, could be not pressed into the middle of the capacity, but buckled outside.

Actually, the first four terms of factorization of aerodynamic coefficient (2) except for zero $a_{0}$ have additional meanings (see table 1), which corresponds to 
the pressure of the covering in the middle of the capacity. Accordingly, they are enough to describe the distorted condition near zero direction.

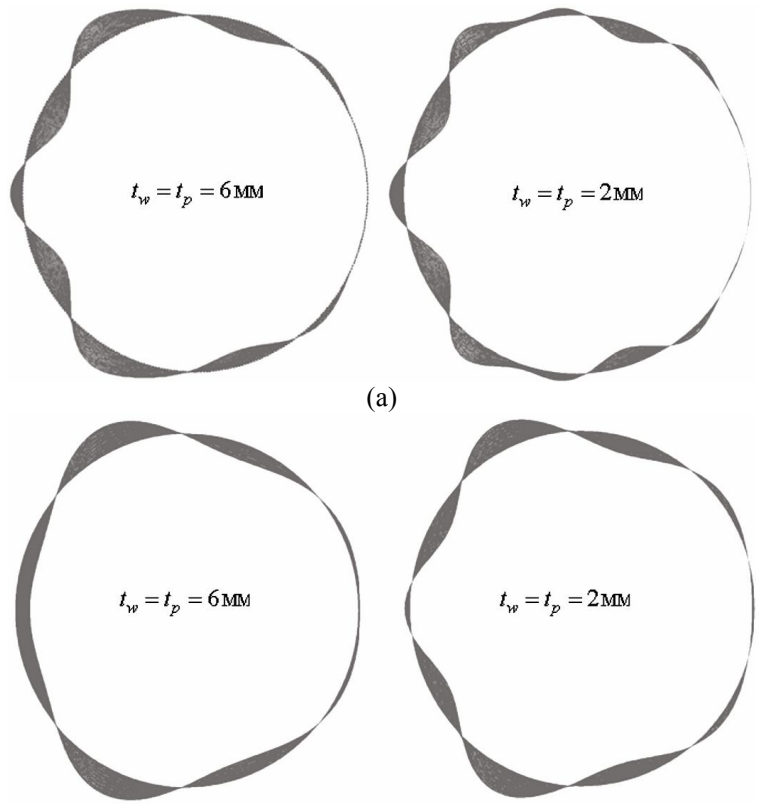

(b)

Fig. 2. Displacements of points of the capacity's body under the wind load by different elongation $\Delta_{w}=H_{w} / D_{w}$ and the thickness of the covering $t_{w}$ and ribs $t_{p}:$ (a) $\Delta_{w}=1$, (б) $\Delta_{w}=3$

Table 1

Values of coefficients when factorizing $C_{a e r}(\varphi)$ into the series by $\cos (k \varphi)$

\begin{tabular}{|c|c|c|c|c|c|c|c|c|c|}
\hline № & $a_{0}$ & $a_{1}$ & $a_{2}$ & $a_{3}$ & $a_{4}$ & $a_{5}$ & $a_{6}$ & $a_{7}$ & $a_{8}$ \\
\hline 5 & $-0,380$ & 0,326 & 0,686 & 0,478 & 0,040 & $\mathrm{H}$ & $\mathrm{H}$ & $\mathrm{H}$ & $\mathrm{H}$ \\
\hline 6 & $-0,380$ & 0,337 & 0,686 & 0,489 & 0,040 & $-0,114$ & $\mathrm{H}$ & $\mathrm{H}$ & $\mathrm{H}$ \\
\hline 7 & $-0,378$ & 0,337 & 0,690 & 0,489 & 0,044 & $-0,114$ & $-0,048$ & $\mathrm{H}$ & $\mathrm{H}$ \\
\hline 8 & $-0,378$ & 0,338 & 0,690 & 0,490 & 0,044 & $-0,113$ & $-0,048$ & $-0,016$ & $\mathrm{H}$ \\
\hline 9 & $-0,377$ & 0,338 & 0,692 & 0,490 & 0,046 & $-0,113$ & $-0,046$ & $-0,016$ & $-0,021$ \\
\hline
\end{tabular}

But to describe in this place reciprocal form of deformation (see fig. 1 (a)), which is characterized by buckling the covering outside, we need higher terms of series (2), which are having negative values. Such characteristics of the deflected mode could not be described without them. So, when we do calculations of short capacities or constructions, which do not have sufficient local bending rigidity, the assessment of parameters of the resulting reaction must be necessarily done at such number of terms in the series $m$, in which not less than two of them must have negative coefficients of factorization $a_{k}$. When calculating relatively high or pretty rigid capacities the assessment of the reaction could be limited by terms 
of series, which have additional coefficients of factorization $a_{k}$. Besides, this conclusion is confirmed from the point of view that the character of deformation of such capacities is smoother, than the capacities of small elongation. And there is no need in trigonometric cosine-functions of higher harmonics to describe the function, which is gradually changing (see fig. 3).
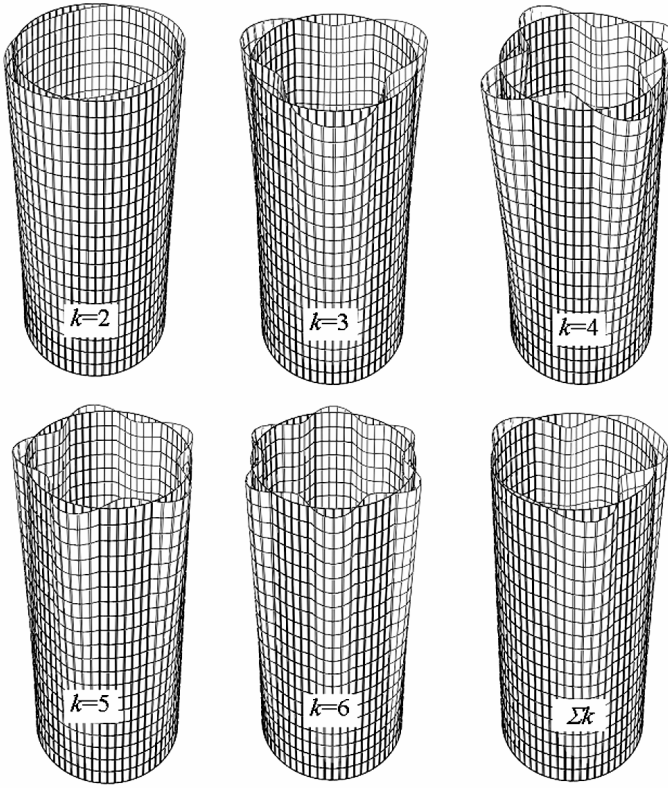

Fig. 3. The spatial character of capacities' deformation by using different harmonics of the trigonometric cosine factorization (2)

It is good to denote that sensitiveness of capacity's reaction to the described above moments is rather different. The most sensitive to the number of series are capacity's displacements, which are directly participate in perception of wind loads, and efforts are less sensitive, since the character of theirs deformation is little changed under the load, when parameters of harmonica are growing.

\section{Conclusions}

1. The most sensitive to the number of series are capacity's displacements, which are directly participate in perception of wind loads.

2. Internal efforts in elements of the capacity are less sensitive, since the character of theirs

deformation is little changed under the load, when parameters of harmonica are growing.

3. When we do calculations of short capacities or constructions, which do not have sufficient local bending rigidity, the assessment of parameters of the resulting reaction must be necessarily done at such number of terms in the series $m$, in which not less than two of them must have negative coefficients of factorization.

4. When calculating relatively high or pretty rigid capacities the assessment of the reaction could be limited by terms of series, which have additional coefficients of factorization $a_{k}$.

\section{REFERENCES}

1. Makhinko A., Makhinko N. Analysis of the deflective mode of thin-walled barrell shell. Academic journal. Industrial Machine Building, Civil Engineering, 2018. - P. 69-78.

2. Vlasov V.Z. Izbrannyye trudy v 3 t. - Moskva: Izdatelstvo Akademii nauk SSSR. 1962-1964. T.1: Ocherk nauchnoy deyatelnosti «Obshchaya teoriya obolochek». Stati. - 1962. - 528 p.; T.2: Tonkostennyye uprugiye sterzhni. Printsipy postroyeniya obshchey tekhnicheskoy teorii obolochek. - 1963. -507 p.; T.3: Tonkostennyye prostranstvennyye sistemy. -1964 . -481 p. 
3. Korobov L.A., Zharkov A.F., Shernik A.O. Dymovye i ventilyatsionnyie truby vysotoy 200-500 metrov, kak prostranstvennye sooruzheniya (Smoke and ventilation pipes with a height of 200500 meters, as spatial structures). - Moskva : KompaniyaSputnik+,2006. - 246 p.

4. Kan S.N. Stroitelnaya mehanika obolochek (Structural mechanics of shells). - Moskva: Mashinostroenie, 1966. - $508 \mathrm{p}$.

5. Kan S.N., Byirsan K.E., Alifanova O.A. Ustoychivost obolochek (Stability of shells). - Harkov, 1970. - 153 p.

6. Kolkunov N.V. Osnovy raschyota uprugih obolochek (Fundamentals of elastic shells analysis). Moskva:Vyisshaya shkola, 1972. - 296 p.

7. Maleki S., Mehretehran A.M. 3D wind buckling analysis of long steel corrugated silos with vertical stiffeners. Engineering Failure Analysis, 2018, Vol. 90, 156-167 pp.

8. Caoa Q.S., Zhaob Y., Zhanga R. Wind induced buckling of large circular steel silos with various slenderness. Thin-Walled Structures, 2018,Vol. 130, 101-113 pp.

9. Chen L., Rotter J.M. Buckling of anchored cylindrical shells of uniform thickness under wind load, Engineering Structures. - Elsevier, 2012. - №41. - P. 199-208.

10. Rotter J.M., Sadowski A.J. Cylindrical shell bending theory for orthotropic shells under general axisymmetric pressure distributions // Engineering Structures. - Elsevier, 2012. - №42. - P. 258-265.

11. Makhinko N.O. Rozrakhunok yemnostei z ploskym dnyshchem, yak obolonok obertannia zminnoi zhorstkosti (Calculation of tanks with flatbottom as evolution shells with variable stiffness). Visnyk Odeskoi derzhavnoi akademii budivnytstva ta arkhitektury. - Odesa: Zovnishreklamservis, 2018. Vol.70. - P.68-74.

\section{Махінько А.В., Махінько Н.О. \\ ДЕЯКІ АСПЕКТИ РОЗРАХУНКУ ВЕРТИКАЛЬНИХ СТАЛЕВИХ СИЛОСІВ НА ДІЮ ВІТРОВИХ НАВАНТАЖЕНЬ}

В даній статті був досліджений вплив параметрів гармоніки несиметричного навантаження, представленого тригонометричними косинусними рядами. Аналіз базується на результатах практичних розрахунків конструкцій силосних установок з використанням теорії моменту про вплив змінного вітрового навантаження. Модель конструкції силосів схематизується у вигляді ортотропної циліндричної оболонки обертання 3 різною приведеною товщиною стінки в меридіональному і круговому напрямках, що дозволяє приблизно, враховуючи наявність вертикальних ребер жорсткості. Нерівномірний розподіл вітрового навантаження за периметром ємності враховувався шляхом розкладання функції аеродинамічного коефіцієнту в скінчений тригонометричний ряд. Отримані значення реакцій відбивалися в безрозмірній полярній системі координат. Чисельне дослідження та графічні схеми переміщень тіл показали, що параметри конструкції (відношення висоти та діаметра ємності, товщини корпусу та їх кількості) впливають на результат розрахунків якісно та кількісно. Для відносно високих або досить жорстких силосів оцінка реакції може бути обмежена членами ряду, які мають додатні коефіцієнти розкладання (перші чотири члени). Характер деформації таких конструкцій досить гладкий і немає потреби в тригонометричних косинусних функціях вищих гармонік для опису функції, яка поступово змінюється. Низькі силоси, які мають відносно невеликий індекс жорсткості ребер і покриттів, не могли бути притиснуті до середини ємності, а вигнуті зовні. Реципрочна форма деформації, яка характеризується вигином покриття зовні, вимагає більш високі члени ряду, які мають від'ємні значення. Отже, для силосів, які не мають достатньої локальної жорсткості на вигин, оцінка параметрів отриманої реакції повинна бути обов'язково проведена на такій кількості членів ряду, в яких не менше двох мають від'ємні коефіцієнти розкладання. Аналіз чутливості реакції силосів показав, що найбільш чутливими до числа рядів $є$ зміщення силосу, а зусилля менш чутливі, оскільки характер їх зміни під навантаженням мало залежить від зростання параметрів гармоніки.

Ключові слова: циліндрична оболонка, несиметричне навантаження, силосна ємність, ребра жорсткості, вітровий вплив, гармоніка навантаження.

\section{Махинько А.В., Махинько Н.А.}

НЕКОТОРЫЕ АСПЕКТЫ РАСЧЕТА ВЕРТИКАЛЬНЫХ СТАЛЬНЫХ СИЛОСОВ НА ДЕЙСТВИЕ ВЕТРОВОЙ НАГРУЗКИ

В данной статье было исследовано влияние параметров гармоники несиметрической нагрузки, представленной тригонометрическим косинус-рядом. Анализ основывался на результатах практических расчетов конструкций силосных емкостей согласно моментной теории на действие переменногй ветровой нагрузки. Модель конструкции силоса 
схематизаровалась в виде ортотропной цилиндрической обоочки вращения с разной приведенной толщиной стенки в мередиональном та кольцевом направлении, что позволило приближенно учесть наличие вертикальных ребер жесткости. Неравномерное распределение ветровой нагрузки по периметру емкости учитывался путем разложения функции аэродинамического коэффициента в конечных тригонометрический ряд. Полученные результаты показали, что наиболее восприимчевыми к количеству членов ряда разложения являются перемещения корпуса емкости. Для относительно высоких силосов достаточно ограничится только положительными значениями коэффициента разложения. Для коротких емкостей необходимо учитывать более высокие члены ряда.

Ключевые слова: цилиндрическая оболочка, несимметрическая нагрузка, силосная емкость, ребра жесткости, ветровое воздействие, гармоника нагрузки.

\section{УДК 624.042}

Махінько А.В., Махінько Н.О. Деякі аспекти розрахунку вертикальних сталевих силосів на дію вітрових навантажень // Опір матеріалів і теорія споруд: наук.-тех. збірн. - К. : КНУБА, 2019. - Вип. 102. - С. 46-52. - Англ.

Розглядається вплив параметрів гармоніки несиметричного завантаження представленого тригонометричним косинус-рядом на базі практичних розрахунків силосних ємностей.

Табл. 1. Іл. 3. Бібліогр. 11 назв.

\section{UDC624.042}

Makhinko A.V., Makhinko N.O. Some aspects of vertical cylindrical shells' calculation at the unsymmetrical load // Strength of Materials and Theory of Structures: Scientific-and-technical collected articles. - Kyiv: KNUBA, 2019. - Issue 102. - P. 46-52. - Eng.

The influence of asymmetric load parameters, which is represented by a trigonometric cosineseries based on design of real silos is considered.

Tabl. 1. Fig. 3. Ref. 11.

\section{УДК 624.042}

Махинько А.В., Махинько Н.A. Некоторые аспекты расчета вертикальных стальных силосов на действие ветровой нагрузки // Сопротивление материалов и теория сооружений: науч.-тех.сборн. - К. : КНУСА, 2019. - Вып. 102. - С. 46-52. - Англ.

Рассматривается влияние параметров гармоники несимметрической нагрузки, представленной тригонометрическим косинус-рядом на основе практических расчетов силосных емкостей.

Табл. 1. Ил. 3. Библиогр. 11 назв.

Автор (вчена ступень, вчене звання, посада):доктор технічних наук, с.н.с, начальник науково-технічного відділу МАХІНЬКО Антон Володимирович

Адреса робоча: 08341 Україна, Київська обл., Бориспільський р-н, с. Петропавлівське, вул. Бортницька, 1, ТОВ «Етуаль», МАХІНЬКУ Антону Володимировичу.

Адреса домашня: 08341, Київська обл., Бориспільський р-н, с. Петропавлівське, вул. Малинна, 79, МАХІНЬКУ Антону Володимировичу.

Роб. тел.: +38(044);

Мобільний тел.: +38(050) 327-27-85;

E-mail: pasargada1981@gmail.com

ORCID ID: http://orcid.org/0000-0002-9147-7087

Автор (вчена ступень, вчене звання, посада): кандидат технічних наук, доцент кафедри комп'ютерних технологій будівництва НН ІАП НАУ МАХІНЬКО Наталія Олександрівна Адреса робоча: 03058, Україна, м. Київ, пр. Космонавта Комарова, 1, Національний авіаційний університет, МАХІНЬКО Наталії Олександрівні.

Адреса домашня: 08341 Київська обл., Бориспільський р-н, с. Петропавлівське, вул. Малинна, 79, МАХІНЬКО Наталії Олександрівні.

Роб. тел.: +38(044) 406-71-60;

Мобільний тел.: +38(050) 304-50-72;

E-mail: pasargada1985@,gmail.com

ORCID ID: http://orcid.org/0000-0001-8120-6374 